\title{
The case for embedding researchers in conservation agencies
}

\author{
Dirk J. Roux (iD ${ }^{1,2}$ Richard T. Kingsford,${ }^{3}$ Carly N. Cook iD,${ }^{4}$ Jane Carruthers, ${ }^{5,6}$ Katrina Dickson, ${ }^{7}$ \\ and Marc Hockings ${ }^{8}$ \\ ${ }^{1}$ Scientific Services, South African National Parks, PO Box 4283, George 6539, South Africa, email dirk.roux@sanparks.org \\ ${ }^{2}$ Sustainability Research Unit, Nelson Mandela University, Private Bag X6531, George 6530, South Africa \\ ${ }^{3}$ Centre for Ecosystem Science, School of Biological, Earth and Environmental Sciences, University of New South Wales, Sydney, \\ NSW 2052, Australia \\ ${ }^{4}$ School of Biological Sciences, Monash University, Clayton, VIC 3800, Australia \\ ${ }^{5}$ Department of History, University of South Africa, P.O. Box 392, Pretoria 0003, South Africa \\ ${ }^{6}$ Centre of Excellence for Invasion Biology, Department of Botany and Zoology, Stellenbosch University, Private Bag X1, Matieland \\ 7602 , South Africa \\ ${ }^{7}$ Australian Centre for Agriculture and Law, University of New England, Armidale, NSW 2351, Australia \\ ${ }^{8}$ School of Earth and Environmental Sciences, University of Queensland, Brisbane, QLD 4072, Australia
}

\begin{abstract}
Although protected areas represent a pivotal response to escalating anthropogenic threats, they face many pressures, inside and outside their boundaries. Amid these challenges, effective conservation is guided by evidence-based decision making supported by dynamic processes of learning and knowledge exchange. Although different models promote knowledge exchange, embedding research scientists within conservation agencies is best suited to supporting evidence-based conservation. Based on available literature and our experiences on several continents, we considered the benefits, challenges, and opportunities associated with embedding research scientists within conservation agencies and the research required to better understand the effectiveness of the embedding model for evidence-based conservation. Embedded researchers provide long-term commitment to building social capital among academic and nonacademic stakeholders; act as skilled gatekeepers who increase 2-way flow of knowledge between scientists and managers; attract, coordinate, and support management-relevant external research projects; drive the design and maintenance of long-term monitoring; and align their research with information needs. Notwithstanding the many benefits, research capacity of conservation agencies is declining worldwide. A significant challenge is that the values, structures, functions, and effectiveness of the embedding model of knowledge exchange remain poorly evaluated and documented. Also, embedded researchers have to balance their desire for creativity and flexibility with the standardization and quality control required by their public sector agencies; may be perceived as not credible because they are not truly independent of their agency; and have to couple scientific productivity with skills for transdisciplinary research, social facilitation, and stakeholder engagement. Systematic research on embedding and other models of knowledge exchange, across different world contexts, is required to better understand the benefits, costs, and institutional arrangements associated with different models.
\end{abstract}

Keywords: enabling conditions, evidence-based conservation, knowledge exchange, protected areas, research needs

El Caso para la Incorporación de Investigadores en las Agencias de Conservación

Resumen: Aunque las áreas protegidas representan una respuesta crucial a las crecientes amenazas antropogénicas, estas enfrentan muchas presiones dentro y fuera de sus fronteras. En medio de estos desafíos, la conservación efectiva se guía por la toma de decisiones con base en evidencias respaldada por los procesos

Article impact statement: Embedding researchers in conservation agencies can promote knowledge exchange, research relevance, and management effectiveness.

Paper submitted July 27, 2018; revised manuscript accepted March 28, 2019. 
dinámicos de aprendizaje e intercambio de conocimiento. Mientras que diferentes modelos promueven el intercambio de conocimiento, la incorporación de investigadores científicos en las agencias de conservación es más adecuada para respaldar la conservación basada en evidencias. Con base en la literatura disponible y en nuestras experiencias en varios continentes consideramos los beneficios, desafíos y oportunidades asociadas con la incorporación de investigadores científicos en las agencias de conservación y la investigación requerida para entender de mejor manera la efectividad del modelo de incorporación para la conservación basada en evidencias. Los investigadores incorporados proporcionan un compromiso a largo plazo con la construcción de un capital social entre los accionistas académicos y no académicos; fungen como guardianes habilidosos que incrementan el flujo de dos vías de conocimiento entre los científicos y los administradores; atraen, coordinan y apoyan los proyectos de investigación externos relevantes para el manejo; llevan el diseño y el mantenimiento del monitoreo a largo plazo; y alinean su investigación con las necesidades de información. A pesar de los beneficios, la capacidad de investigación de las agencias de conservación está declinando a nivel mundial. Un desafío significativo es que los valores, estructuras, funciones y efectividad del modelo de incorporación del intercambio de conocimiento permanecen pobremente evaluados y documentados. Además, los investigadores incorporados tienen que balancear su deseo por ser creativos y flexibles con la estandarización y el control de calidad requeridos por sus agencias del sector público; pueden ser percibidos como no creíbles porque no son realmente independientes de su agencia; y tienen que emparejar la productividad científica con las habilidades de investigación transdisciplinaria, facilitación social y participación de los accionistas. Se requiere de la investigación sistemática sobre la incorporación y otros modelos de intercambio de conocimiento en diferentes contextos globales para entender de mejor manera los beneficios, costos y arreglos institucionales asociados con diferentes modelos.

Palabras Clave: áreas protegidas, condiciones habilitantes, conservación basada en la evidencia, intercambio de conocimiento, necesidades de investigación

\begin{abstract}
摘要: 保护地在当前人为威胁不断升级的现状下对保护起着关键作用, 然而, 在保护地的边界内外都面临着许多 压力。为应对这些压力和挑战,需要那些被动态学习过程和知识交换支持的基于证据的决策来指导有效保护。 尽管许多不同的模式都可以促进知识交换, 但在保护机构中吸纳科学家的做法才最能支持基于证据的保护。根 据现有的文献和我们在多个大洲的经验, 我们探讨了将研究者纳人保护机构的好处、挑战和机遇, 以及为了更 好地理解吸纳研究者的模式对基于证据的保护的有效性仍需进行的研究。加人保护机构的研究者会长期致力 于建立学术界和非学术界的利益相关者之间的社会资本; 担当把关人来增加科学家和管理者之间的双向知识交 流; 吸引、协调和支持与管理相关的外部研究项目; 推动长期监测项目的设计和维护; 并根据信息需求来进行他 们的研究。虽然这样做有许多好处, 但世界范围内, 保护机构的研究能力却正在下降。目前面临的一个重要挑 战在于, 这种人才吸纳式的知识交换模式的价值、结构、功能和有效性仍然没有得到很好的评估和记录。此外, 研究者必须在对创造力和灵活性的渴望与公共部门机构要求的标准化和质量控制之间取得平衡, 可能会因为并 非完全独立于他们的服务机构而被认为不可信; 还必须将科学生产力与跨学科研究、社会促进和推动利益相关 者参与等技能相结合。为了更好地理解各种知识交换模式的利益、成本和制度安排, 未来需要对不同领域背景 下的人才吸纳及其它模式进行系统性的研究。【翻译: 胡怡思; 审校: 聂永刚】
\end{abstract}

关键词: 基于证据的保护, 支持条件, 知 识交换, 保护地, 研究需求

\section{Introduction}

Human domination of Earth has changed its climate, landscapes, ecosystems, and ecological processes and threatens to destabilize critical systems for sustaining life (Steffen et al. 2007; Barnosky et al. 2012). Society's most significant response is to protect nature in selected areas (Watson et al. 2014; Ferraro \& Pressey 2015). Since the 1960s, the global number of protected areas (PAs) has grown rapidly to more than 200,000 , covering $14.7 \%$ $\left(19.8\right.$ million $\mathrm{km}^{2}$ ) of the world's terrestrial extent and $4.1 \%$ (14.9 million $\mathrm{km}^{2}$ ) of global oceans (UNEP-WCMC and IUCN 2016).

Effective governance of PAs is vital to the future wellbeing of humans, but many factors hinder their potential (Watson et al. 2014). These include rapid loss of environments for potential future PAs; downgrading, down- sizing, and degazettement of existing PAs (Mascia et al. 2014); and declining investment in PAs (Watson et al. 2014). Furthermore, a third of global PAs have intense human pressures inside their boundaries (Jones et al. 2018), and many PAs are small, which increases exposure to "edge effects" from surrounding landscapes (Janzen 1983).

In addition to conserving biodiversity, PAs are increasingly expected to provide social and economic benefits commensurate with alternative land uses (Halpern et al. 2009; Sayer et al. 2013; Mascia et al. 2014). No longer are PAs islands buffered from surrounding development; rather, they are social-ecological systems within landscapes (Palomo et al. 2014; Cumming et al. 2015). PAs influence and are influenced by external social, economic, environmental, and political contexts across local, regional, and even global scales (Palomo et al. 2014; 
Cumming et al. 2015). Stakeholder values, societal needs, competing land uses, attitudes toward conservation, resource extraction, and convoluted policy contexts add complexity to PA management (Archabald \& NaughtonTreves 2001; Defries 2017). Many organisms and ecological processes cannot be maintained solely by PAs; thus, management of threatening processes outside PA boundaries is required.

Research in PAs can generate novel insights into natural processes and social-ecological feedbacks to support evidence-based management of these complex systems and their surrounds. However, despite the importance of evidence-based conservation (Pullin \& Knight 2001; Sutherland et al. 2004), conservation science only modestly contributes to improved management and governance of PAs (Knight et al. 2008). Requisite evidence is rarely accessible to managers in a useful format or at the right time, even though they value it for decisions (Cook et al. 2012). In over 8000 PAs from 100 countries, research and monitoring contributed relatively poorly to management effectiveness, compared with appropriate design, legislation, and demarcation of boundaries (Leverington et al. 2010). In North America, many wildlife management decisions are not underpinned by science (Artelle et al. 2018). For example, perceptions of PA managers in the Tennessee and Cumberland River Basins about the status of their freshwater ecosystems were not supported by scientific evidence (Thieme et al. 2012). Similarly, few conservation managers from 1000 PAs in Australia used scientific knowledge to support their management (Cook et al. 2010).

Several models of knowledge exchange between scientists and managers have emerged to improve evidencebased decision making in conservation (Fig. 1) (Fazey et al. 2013; Cvitanovic et al. 2015). They include coproduction of knowledge by scientists and decision makers (Van Kerkhoff \& Lebel 2015; Nel et al. 2016), with either intermediaries between knowledge producers and end users within research institutions (i.e., knowledge brokers) (Chapman et al. 2017; Maag et al. 2018) or independent of research and management institutions (i.e., boundary organizations) (Guston 2001; Crona \& Parker 2012). Arguably, the most poorly understood model is embedding scientists within management agencies (Fig. 1) (Cook et al. 2013; Roux et al. 2015). This includes dedicated science personnel who act as knowledge brokers (Cvitanovic et al. 2015) and those who actively conduct research (i.e., research scientists), including publishing in peer-reviewed journals (Jenkins et al. 2012; Cook et al. 2013; Roux et al. 2015).

Knowledge exchange is rarely evaluated (Fazey et al. 2014), particularly for embedded scientists, such that the values, structures, functions, and effectiveness of this model are poorly documented. Drawing on available literature and our experience on several continents, we considered the value of embedding research scientists within conservation agencies over models of knowledge exchange that use intermediaries to promote communication between scientists and decision makers. We also considered challenges and opportunities associated with institutionalizing the embedding model and the research required to better understand the effectiveness of embedding research scientists for evidence-based conservation.

\section{Value of Embedding Scientists Within Conservation Agencies}

Where embedded scientists exist, they typically represent a small proportion (1-5\%) of conservation agency staff (Roux et al. 2015). They are permanent employees providing long-term commitment for building social networks, trust, and social capital among academic and nonacademic stakeholders for effective knowledge exchange (Chapman et al. 2017).

\section{Embedding Scientists Versus Outsourcing Research}

Outsourcing management-relevant research has failed to achieve evidence-based conservation for several reasons. First, the incentive structures for academic researchers often mean that management-relevant research is undervalued by external researchers because it can be idiosyncratically local (Kingsford 2018). As such, external researchers rarely build the trust and relationships that come from long-term commitment (Chapman et al. 2017) or conduct the long-term research essential to address many important management questions (Cook et al. 2013). Research in PAs often benefits external researchers and their institutions, rather than PA managers and the broad society (e.g., research in the Spanish National Parks of Doñana and Sierra Nevada [Moreno et al. 2014]).

Second, the distribution of research (peer-reviewed articles) tends to be highly skewed toward particular PAs, as in 442 PAs in Amazonian countries (Correia et al. 2016), 21 national parks in South Africa (Van Wilgen et al. 2016), and 15 well-known PAs in Africa (Smit et al. 2017). This was partly driven by older, larger, and more accessible (e.g., geographic proximity to collaborating universities) PAs attracting more external researchers. Researchers were influenced by previous pioneering research (Correia et al. 2016), availability of dedicated facilities (Van Wilgen et al. 2016), and opportunities to collaborate with agency researchers and technicians (Smit et al. 2017).

Third, the potential of external research to inform PA management is constrained by a disciplinary bias in conservation science, dominated by ecological research (Roux et al. 2015; Velasco et al. 2015; Van Wilgen et al. 2016). Although ecosystem understanding is critical, social science is increasingly important (Bennett et al. 


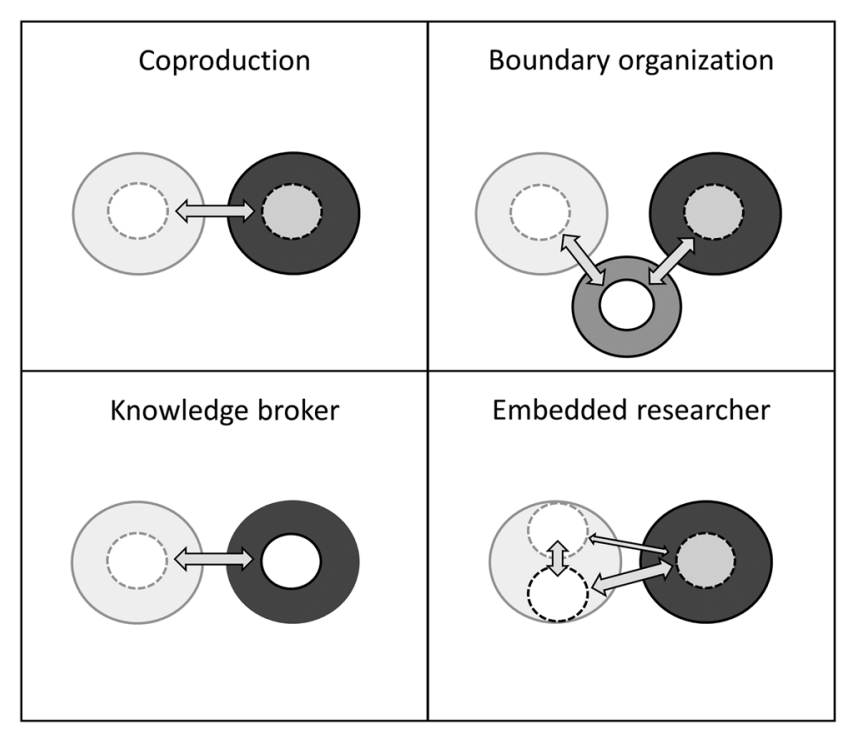

2017). Effective conservation relies on economics, natural resource governance, anthropology, communications, psychology, sociology, ethics, political science, and climate science (Kareiva \& Marvier 2012).

Fourth, conventional disciplinary research seldom addresses the important human-nature interactions and complex feedbacks among system components and scales, characteristic of PAs nested within and connected to other social-ecological systems (Palomo et al. 2014; Cumming et al. 2015). Inherently complex socialecological problems require integrative, adaptive, systemic, and socially engaged research approaches that promote ongoing and collaborative learning and integration of knowledge across disciplines, sectors, scales, and science-policy-practice realms (Sayer et al. 2013; Van Kerkhoff 2014). Such problem-focused, transdisciplinary research, with strong colearning, departs substantially from conventional and disciplinary modes of inquiry (Van Kerkhoff 2014) and is seldom amenable to short-term project funding (Roux et al. 2010).

\section{Benefits of Embedded Scientists as Knowledge Brokers}

Knowledge brokers are generally conceived as being embedded within research institutions (e.g., Cvitanovic et al. 2015), but scientists embedded within conservation agencies also play this role. Here, they act as skilled gatekeepers who increase the likelihood that priority knowledge needs are communicated to and addressed by external researchers and that new scientific knowledge is translated and communicated back to decision makers and stakeholders (Jenkins et al. 2012; Cvitanovic et al. 2015; Roux et al. 2017). Embedded scientists can constantly engage with decision makers, unencumbered by short-term project funding cycles (Farwig et al. 2017). They can also collaborate on external research projects

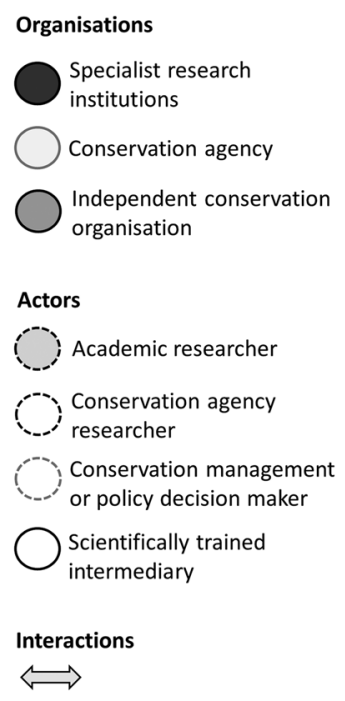

Figure 1. Generalized depiction of 4 different models (coproduction, boundary organization, knowledge broker, and embedded research) of knowledge exchange, which are not mutually exclusive. Arrows and arrow width indicate direction and strength, respectively, of communication among different actors (modified from Cvitanovic et al. 2015).

(Van Wilgen et al. 2016; Smit et al. 2017), promoting coproduction of knowledge.

Embedded scientists also attract and support management-relevant external research projects. Research support was the highest ranked motivator and enabling condition for external research in Kruger National Park (Smit et al. 2017). Such support takes various forms (Table 1), including maintenance of long-term monitoring programs. Monitoring underpins ecosystem management, allowing evaluation of management effectiveness and ongoing improvement of management plans. Monitoring is also critical for tracking the mitigation of threatening processes and for reporting important trends to managers, local communities, visitors, and other stakeholders (Hockings et al. 2013). Embedded scientists can drive the design and maintenance of long-term monitoring that is aligned with management priorities (Carruthers 2017). They also solicit data analyses by external scientists, as with river (McLoughlin et al. 2011) and fire management (Van Wilgen et al. 2007) in Kruger National Park.

Furthermore, embedded scientists incorporate feedbacks from monitoring into the formal and informal learning within agencies, including rigorous and collaborative documentation (Smit et al. 2017) and adaptive management (Biggs \& Rogers 2003). Embedded scientists also support adaptive and transformative learning within their organizations, sometimes at odds with prevailing bureaucratic cultures (Dickson et al. 2019). They also maintain an influential role in colearning processes with key stakeholders, which promotes new understanding and behavior across social-ecological systems that transcend PA boundaries. For example, the U.S. National Park Service engaged in extensive interagency and science-policy-management-stakeholder collaborations to address air pollution originating outside park boundaries (Baron et al. 2017), and agency 
Table 1. Examples of research support provided by conservation agencies to promote management-relevant research.

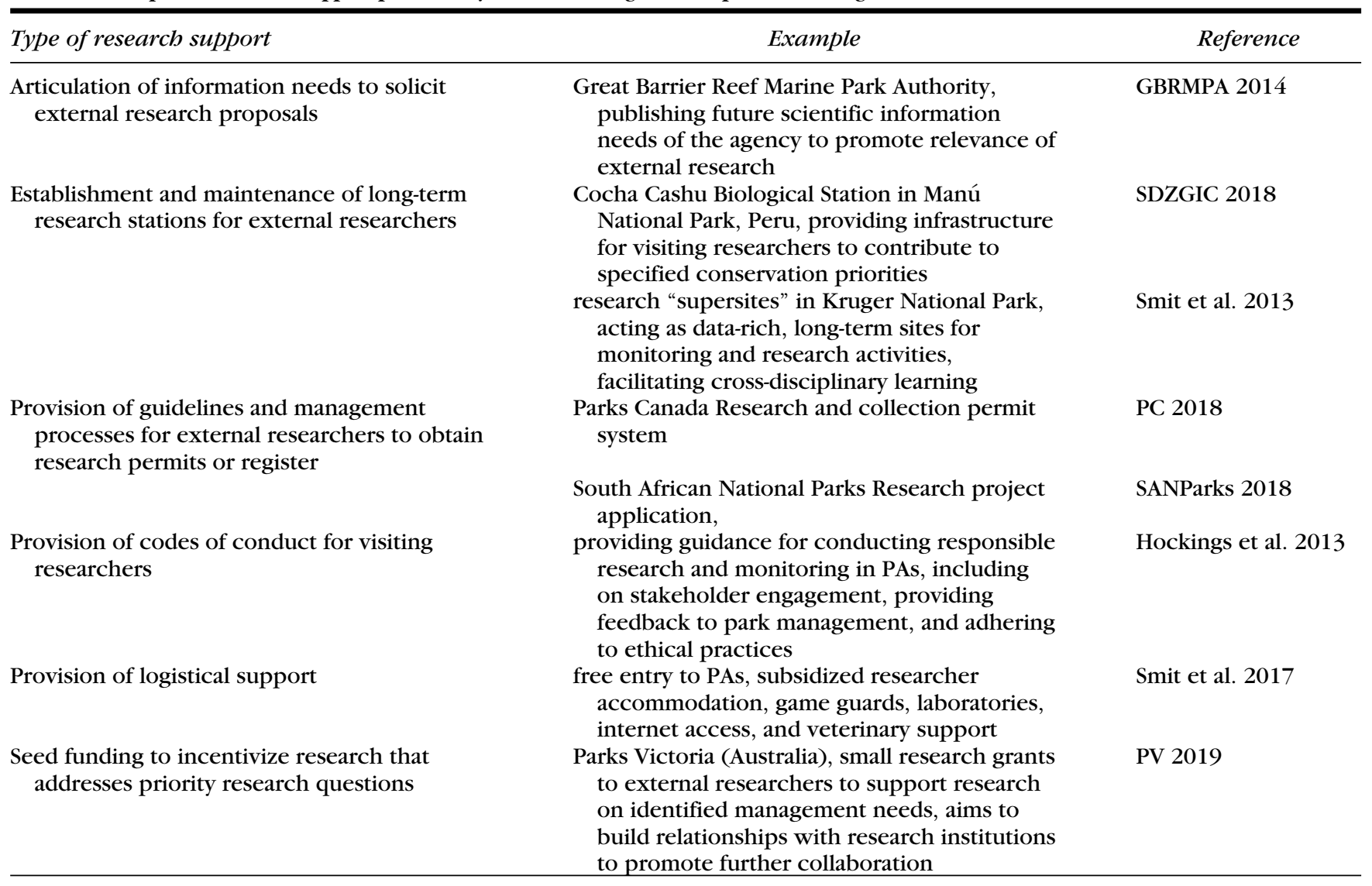

scientists reconnected stakeholders across several boundaries to restore river flows in Kruger National Park (Biggs et al. 2017).

\section{Embedded Scientists as Active Researchers}

There are additional advantages to embedded scientists being active researchers. Active researchers can quickly respond to emerging information needs (Jenkins et al. 2012) by addressing mundane questions that may not attract interest from academic researchers (Farwig et al. 2017) but are essential for management (Cook et al. 2013). For example, agency researchers in Australia classified and mapped wetlands (Kingsford et al. 2004), described and mapped vegetation classes (Keith 2004), and identified fire-return intervals (Kenny et al. 2004). These management needs were unlikely to attract external research funding, and yet they were central to key strategic decision making for PAs and related conservation policies. In South Africa, the strategic adaptive management paradigm emerged from within the national park agency (South African National Parks) and was driven by a cohort of researchers and managers in search of local solutions (Biggs \& Rogers 2003).

Practicing agency researchers keep up-to-date with the ever-growing scientific literature in their fields, identify relevant research, assess its quality and applicability to management decisions, and translate findings into management (Murray et al. 2011; Cook et al. 2013; Roux et al. 2015). They also formally synthesize available evidence for policy (e.g., risks of wind farms to bird species in PAs [Stewart et al. 2007]) or management (e.g., use of herbicides compared with physical removal of invasive vegetation [Tyler et al. 2006]). Furthermore, they informally transfer knowledge by organizing sciencemanagement forums, cocreating social-ecological systems models with managers and other stakeholders (Gaylard \& Ferreira 2011), and engaging with the media.

A small unit of active embedded researchers can significantly promote the relevance and uptake of scientific evidence in PAs. For example, researchers embedded within SANParks were catalysts for long-term monitoring, investment in research infrastructure, extensive collaboration with academics, and implementation of adaptive management. They established a synergistic relationship between science and management, which delivered evidence-based decision making and thus improved effective conservation (Carruthers 2017).

\section{Challenges and Opportunities of Embedded Researchers}

In our experience, research capacity of conservation agencies is declining across the world. Embedded 
research units are increasingly vulnerable to budget cuts and restructures (Watson et al. 2014) because some argue that most PA-related research can be done by external researchers. Further challenges include little guidance in the formal literature or institutional mechanisms within conservation agencies to support an embedded research capacity.

We have observed enabling conditions that produce outstanding examples of embedded researchers within conservation agencies. Most notably, supportive and enabling senior leaders in agencies are critical for maximizing benefits of embedded research. Leaders overseeing research units in public sectors have to manage the tension between standardization and quality control on the one side and innovation and flexibility on the other. Enabling leadership is characterized by the creation of safe learning spaces for new ideas to form from experimentation, reflection, colearning (including engagement outside the agency), and adaptive implementation. Furthermore, enabling leaders support embedded research by aiding the flow of new insights and creativity into relevant management and policy (Uhl-Bien et al. 2007) and supporting evidence that sometimes may not align with current policy or management.

Agency researchers can also be leaders in conservation science. As "integrative leaders," they influence policy makers, managers, stakeholders, and researchers to advance use of scientific evidence in policy and management (Manolis et al. 2009). As well as their own research, such integrative leaders need to recognize the social dimension of conservation problems, cycle effectively through periods of action and reflection, capture the attention of diverse audiences, and influence social networks (Manolis et al. 2009). Enabling senior leadership and integrative leadership of agency researchers can be mutually reinforcing.

The most successful embedded research units maintain their scientific credibility through publishing in peerreviewed journals, attending scientific meetings, and participating in specialized knowledge networks. Scientific credibility, achieved through peer-reviewed research outputs, must also be coupled with a strong emphasis on practical relevance (Roux et al. 2015). This dual job function requires suitably tailored and flexible performance measures that acknowledge the skills and resources needed for research and knowledge exchange across diverse networks of stakeholders. For example, researchers in the New South Wales Government conservation agency have a clear career path and are rewarded for scientific publications and contributions to policy and management outcomes (e.g., Department of Premier and Cabinet 2011).

There is also the challenge of external credibility of embedded researchers who are not truly independent from their agency (Cook et al. 2013). Extensive external collaborations by embedded researchers can offset this perspective (Roux et al. 2015; Van Wilgen et al. 2016; Smit et al. 2017). Joint or adjunct positions with universities promote desirable networking and collaboration with the academic community and provide the added benefits of access to primary literature and postgraduate students (Cook et al. 2013). However, where embedded researchers hold such positions with universities, careful management is required to ensure workload balance, appropriate alignment of research with agency needs, and ongoing knowledge exchange among embedded researchers, managers, and policy makers.

For embedded research to succeed, it requires strong depth and breadth of relevant disciplinary knowledge balanced with skills for transdisciplinary research, social facilitation, and stakeholder engagement. Disciplinary makeup will vary across agencies and over time. However, historical biophysical biases still remain (Roux et al. 2015), which may be difficult to overcome due to reinforcing feedbacks associated with discipline-specific collaborators and mentoring of junior researchers. Complex social-ecological issues are a new research frontier that adds urgency to the mainstreaming of social sciences in addressing many conservation challenges (Bennett et al. 2017) and emphasizes the importance of relational skills for conducting socially engaged research. Some complex conservation problems may best be addressed by "sustainability scientists" who are epistemologically agile and can thus facilitate knowledge sharing and coproduction among social scientists, natural scientists, stakeholders, policy makers, and managers (Haider et al. 2017).

\section{Opportunities to Support Embedded Researchers}

Establishment and maintenance of embedded researchers relies on bottom-up and top-down processes in conservation practice. For many conservation agencies, legislative responsibilities for PA management are idiosyncratic, so establishment of an embedded function is likely to be more successful if founded on bottom-up (national or regional) processes. Leadership critically establishes policy and culture for the operating framework and articulates the importance of science and innovation in solving complex problems with decision making supported by scientific evidence.

Stipulation of a research function in legislation could strengthen the case for embedded science, ensuring its longevity in the face of idiosyncratic changes in policy, culture, or budgets. International conventions and organizations can also be important vehicles for legislative and policy change, as in the case of management effectiveness evaluation, where advocacy by the IUCN World Commission on Protected Areas achieved the inclusion of management effectiveness evaluation in the Programme of Work on Protected Areas of the Convention on Biological Diversity (Hockings et al. 2004). Such international support for an embedded science model could be a 
catalyst for institutionalizing an embedded science function in conservation agencies around the world.

\section{Research Needs}

Benefits of knowledge-exchange strategies remain poorly evaluated (Fazey et al. 2014). There are merits to investing in embedded researchers, but empirical data on its benefits for effective decision making or improved policy and management in conservation or natural resource management remain absent. Evidence from other public-sector fields (medicine, agriculture, and fisheries) with embedded scientific capacities suggests benefits. For example, public funding of agricultural research in the United States, including for state experimental stations and intramural research, is positively correlated with economic benefits (Andersen 2015). Also, industrial firms increase their ability to identify, acquire, assimilate, transform, and exploit relevant external knowledge (their absorptive capacity) if they develop complementary knowledge through their own research and development, increasing their profitability and competitiveness (Cohen \& Levinthal 1990; Murray et al. 2011). Assessment of the costs and benefits of our recommended embedding model, particularly relative to models that out-source research capacity, is needed. Collecting such empirical evidence would be an important motivator for agencies to either invest in or retaining an embedded research capacity.

Most conservation agencies are public sector organizations (UNEP-WCMC \& IUCN 2016) but they vary widely in form and function across the globe. Little information is available on the prevalence of the embedding model among these agencies and how this may have changed over time. There is little beyond case-study evidence that addresses the arrangements by which researchers are incorporated, managed, and supported within conservation agencies; the costs and benefits of such arrangements; and whether institutional changes have led to the anecdotal decline in agency research capacity.

\section{Conclusion}

Although PAs have enormous potential as strategic research sites, relatively few appear to be used as such. Furthermore, research undertaken in PAs, and conservation science more generally, often fail to inform effective PA management. Embedding research capacity in conservation agencies can unlock the potential of external researchers working in PAs by promoting parks for science and science for parks. Embedded researchers are well positioned to keep their research grounded in practice and to promote management-relevant science that impacts conservation policy and practice. They can also spearhead transdisciplinary approaches that are necessary to address complex social-ecological conservation problems affecting PAs. Furthermore, they can serve as bridging agents between learning and doing (e.g., through adaptive management) and thus advance knowledge exchange among scientists and decision makers and colearning with diverse stakeholders to promote new understanding and behavior throughout social-ecological systems. Given these benefits, embedding research scientists in conservation agencies deserves more formal attention and investment.

Although we highlight examples where embedded researchers have provided significant value, more data are required on models for embedding science in conservation agencies and associated costs and benefits. It is unlikely that a single model will suit, or be feasible for, all world contexts. A more systematic evaluation of bridging functions employed (or not) by a representative sample of conservation agencies across the world is required. This could be done under the auspices of the International Union for Conservation of Nature (IUCN), an organization best positioned to access information from PAs and to encourage global implementation. The next World Parks Congress due in 2024 provides an excellent opportunity to consolidate current knowledge and develop good-practice guidelines.

\section{Acknowledgments}

The article was developed by an informal Working Group of the IUCN World Commission on Protected Areas. G. Cumming provided encouragement and valuable suggestions during the process. Constructive comments from the handling editor, G. Castley, and 2 anonymous reviewers helped us improve on an earlier version of the manuscript. Senior editor, E. Main, provided professional copyediting.

\section{Literature Cited}

Andersen MA. 2015. Public investment in US agricultural R\&D and the economic benefits. Food Policy 51:38-43

Archabald K, Naughton-Treves L. 2001. Tourism revenue-sharing around national parks in Western Uganda: early efforts to identify and reward local communities. Environmental Conservation 28:135-149.

Artelle KA, Reynolds JD, Treves A, Walsh JC, Paquet PC, Darimont CT. 2018. Hallmarks of science missing from North American wildlife management. Science Advances 4:eaao0167.

Barnosky AD, et al. 2012. Approaching a state shift in Earth's biosphere. Nature 486:52-58.

Baron JS, Blett T, Malm WC, Alexander RM, Doremus H. 2017. Protecting national parks from air pollution effects: making sausage from science and policy. Pages 141-160 in Beissinger SR, Ackerly DD, Doremus H, Machlis GE, editors. Science, conservation, and national parks. The University of Chicago Press, Chicago, Illinois.

Bennett NJ, et al. 2017. Mainstreaming the social sciences in conservation. Conservation Biology 31:56-66. 
Biggs HC, Clifford-Holmes JK, Freitag S, Venter FJ, Venter J. 2017. Crossscale governance and ecosystem service delivery: a case narrative from the Olifants River in north-eastern South Africa. Ecosystem Services 28:173-184.

Biggs H, Rogers KH. 2003. An adaptive system to link science, monitoring and management in practice. Pages 59-80 in Du Toit JT, Rogers KH, Biggs HC, editors. The Kruger Experience: ecology and management of savanna heterogeneity. Island Press, Washington, D.C.

Carruthers J. 2017. National park science: a century of research in South Africa. Cambridge University Press, Cambridge, United Kingdom.

Chapman K, et al. 2017. Knowledge that acts: evaluating the outcomes of a knowledge brokering intervention in Western Australia's Ningaloo region. Environmental Management 60:896-907.

Cohen WM, Levinthal DA. 1990. Absorptive capacity: a new perspective on learning and innovation. Administrative Science Quarterly 35:128-152.

Cook CN, Carter RB, Fuller RA, Hockings M. 2012. Managers consider multiple lines of evidence important for biodiversity management decisions. Journal of Environmental Management 113:341-346.

Cook CN, Hockings M, Carter RW. 2010. Conservation in the dark? The information used to support management decisions. Frontiers in Ecology and the Environment 8:181-186.

Cook CN, Mascia MB, Schwartz MW, Possingham HP, Fuller RA. 2013. Achieving conservation science that bridges the knowledge-action boundary. Conservation Biology 27:669-678.

Correia RA, Malhado AC, Lins L, Gamarra NC, Bonfim WA, ValenciaAguilar A, Bragagnolo C, Jepson P, Ladle RJ. 2016. The scientific value of Amazonian protected areas. Biodiversity and Conservation 25:1503-1513.

Crona BI, Parker JN. 2012. Learning in support of governance: theories, methods, and a framework to assess how bridging organizations contribute to adaptive resource governance. Ecology and Society 17:32.

Cumming GS, et al. 2015. Understanding protected area resilience: a multi-scale, social-ecological approach. Ecological Applications 25:299-319.

Cvitanovic C, Hobday AJ, Van Kerkhoff L, Wilson SK, Dobbs K, Marshall NA. 2015. Improving knowledge exchange among scientists and decision-makers to facilitate the adaptive governance of marine resources: a review of knowledge and research needs. Ocean \& Coastal Management 112:25-35.

Defries R. 2017. The tangled web of people, landscapes, and protected areas. Pages 227-246 in Beissinger SR, Ackerly DD, Doremus H, Machlis GE, editors. Science, conservation, and national parks. The University of Chicago Press, Chicago, Illinois.

Department of Premier and Cabinet. 2011. Research scientists classification-policy and guidelines. Department of Premier and Cabinet, New South Wales, Sydney, Australia.

Dickson K, Bartel R, Roux D, Alter T. 2019. Achieving organisational learning in natural resource management agencies. Chapter 3 in Martin P, Alter T, Hine D, Howard T, editors. Community-based control of invasive species. CSIRO Publishing, Victoria, Australia. In press.

Farwig N, et al. 2017. Bridging science and practice in conservation: deficits and challenges from a research perspective. Basic and Applied Ecology 24:1-8.

Fazey I, Bunse L, Msika J, Pinke M, Preedy K, Evely AC, Lambert E, Hastings E, Morris S, Reed MS. 2014. Evaluating knowledge exchange in interdisciplinary and multi-stakeholder research. Global Environmental Change 25:204-220.

Fazey I, et al. 2013. Knowledge exchange: a review and research agenda for environmental management. Environmental Conservation 40:19-36.

Ferraro PJ, Pressey RL. 2015. Measuring the difference made by conservation initiatives: protected areas and their environmental and social impacts. Philosophical Transactions of the Royal Society B 370:20140270.

Gaylard A, Ferreira S. 2011. Advances and challenges in the implementation of strategic adaptive management beyond the Kruger National Park-making linkages between science and biodiversity management. Koedoe 53:58-65.

GBRMPA (Great Barrier Reef Marine Park Authority). 2014. Science strategy and information needs 2014-2019. GBRMPA, Townsville, Australia. Available from http://elibrary.gbrmpa.gov.au/ jspui/handle/11017/2872 (accessed October 2018).

Guston DH. 2001. Boundary organizations in environmental policy and science: an introduction. Science, Technology and Human Values 26:339-408.

Haider LJ, et al. 2017. The undisciplinary journey: early-career perspectives in sustainability science. Sustainability Science 13:191-204.

Halpern BS, Lester SE, Kellner JB. 2009. Spillover from marine reserves and the replenishment of fished stocks. Environmental Conservation 36:268-276.

Hockings M, Adams WM, Brooks TM, Dudley N, Jonas H, Lotter W, Mathur V, Väisänen R, Woodley S. 2013. A draft code of practice for research and monitoring in protected areas. PARKS 19:85-94.

Hockings M, Ervin J, Vincent G. 2004. Assessing the management of protected areas: the work of the World Parks Congress before and after Durban. Journal of International Wildlife Law and Policy 7: $1-12$.

Janzen DH. 1983. No park is an island: increase in interference from outside as park size decreases. Oikos 41:402-410.

Jenkins LD, Maxwell SM, Fisher E. 2012. Increasing conservation impact and policy relevance of research through embedded experiences. Conservation Biology 26:740-742.

Jones KR, Venter O, Fuller RA, Allan JR, Maxwell SL, Negret PJ, Watson JEM. 2018. One-third of global protected land is under intense human pressure. Science 360:788-791.

Kareiva P, Marvier M. 2012. What is conservation science? BioScience 62:962-969.

Keith DA. 2004. Ocean shores to desert dunes: the native vegetation of New South Wales and the ACT. New South Wales Department of Environment and Conservation, Sydney, Australia.

Kenny B, Sutherland E, Tasker E, Bradstock R. 2004. Guidelines for ecologically sustainable fire management. NSW National Parks and Wildlife Service, Sydney, Australia.

Kingsford RT. 2018. Zoom in on the big picture. Academic reward structures discourage the pursuit of vital research. Nature 558:S21.

Kingsford RT, Brandis K, Thomas RF, Knowles E, Crighton P, Gale E. 2004. Classifying landform at broad landscape scales: the distribution and conservation of wetlands in New South Wales, Australia. Marine and Freshwater Research 55:17-31.

Knight AT, Cowling RM, Rouget M, Balmford A, Lombard AT, Campbell BM. 2008. Knowing but not doing: selecting priority conservation areas and the research-implementation gap. Conservation Biology 22:610-617.

Leverington F, Costa KL, Pavese H, Lisle A, Hockings M. 2010. A global analysis of protected area management effectiveness. Environmental Management 46:685-698.

Maag S, Alexander TJ, Kase R, Hoffmann S. 2018. Indicators for measuring the contributions of individual knowledge brokers. Environmental Science and Policy 89:1-9.

Manolis JC, Chan KM, Finkelstein ME, Stephens S, Nelson CR, Grant JB, Dombeck MP. 2009. Leadership: a new frontier in conservation science. Conservation Biology 23:879-886.

Mascia MB, et al. 2014. Protected area downgrading, downsizing, and degazettement (PADDD) in Africa, Asia, and Latin America and the Caribbean, 1900-2010. Biological Conservation 169:355361.

McLoughlin CA, Deacon A, Sithole H, Gyedu-Ababio T. 2011. History, rationale, and lessons learned: thresholds of potential concern in 
Kruger National Park river adaptive management. Koedoe 53:75101

Moreno J, Palomo I, Escalera J, Martín-López B, Montes C. 2014. Incorporating ecosystem services into ecosystem-based management to deal with complexity: a participative mental model approach. Landscape Ecology 29:1407-1421.

Murray K, Roux DJ, Nel JL, Driver A, Freimund W. 2011. Absorptive capacity as a guiding concept for effective public sector management and conservation of freshwater ecosystems. Environmental Management 47:917-925.

Nel JL, Roux DJ, Driver A, Hill L, Maherry AC, Snaddon K, Petersen CR, Smith-Adao LB, Van Deventer H, Reyers B. 2016. Knowledge co-production and boundary work to promote implementation of conservation plans. Conservation Biology 30:176-188.

Palomo I, Montes C, Martín-López B, González JA, García-Llorente M, Alcorlo P, Mora MRG. 2014. Incorporating the social-ecological approach in protected areas in the Anthropocene. BioScience 64:181191.

PC (Parks Canada). 2018. Research and collection permit system. Parks Canada, Quebec, Canada. Available from https://www.pc. gc.ca/apps/rps/page1_e.asp (accessed October 2018).

PV (Parks Victoria). 2019. Research partners program. PV, Melbourne, Australia. Available from https://parkweb.vic.gov.au/parkmanagement/environment/research-and-scientific-management/ research/research-partners-program (accessed January 2019).

Pullin AS, Knight TM. 2001. Effectiveness in conservation practice: pointers from medicine and public health. Conservation Biology 15:50-54.

Roux DJ, Kingsford RT, McCool SF, McGeoch MA. Foxcroft LC. 2015. The role and value of conservation agency research. Environmental Management 55:1232-1245.

Roux DJ, Nel JL, Cundill G, O'Farrell P, Fabricius C. 2017. Transdisciplinary research for systemic change: who to learn with, what to learn about and how to learn. Sustainability Science 12:711726.

Roux DJ, Stirzaker RJ, Breen CM, Lefroy EC, Cresswell HP. 2010. Framework for participative reflection on the accomplishment of transdisciplinary research programs. Environmental Science \& Policy 13:733-741.

SDZGIC (San Diego Zoo Global Institute for Conservation). 2018. Cocha Cashu Biological Station. SDZGIC, Cusco, Peru. Available from https://cochacashu.sandiegozooglobal.org/ (accessed October 2018).

Sayer J, et al. 2013. Ten principles for a landscape approach to reconciling agriculture, conservation, and other competing land uses. Proceedings of the National Academy of Sciences 110:83498356.

Smit IPJ, Riddell ES, Cullum C, Petersen R. 2013. Kruger National Park research supersites: establishing long-term research sites for cross-disciplinary, multiscaled learning. Koedoe $\mathbf{5 5}$ https://doi.org/10.4102/koedoe.v55i1.1107.
Smit IPJ, Roux DJ, Swemmer LK, Boshoff N, Novellie P. 2017. Protected areas as outdoor classrooms and global laboratories: intellectual ecosystem services flowing to-and-from a National Park. Ecosystem Services 28:238-250.

SANParks (South African National Parks) 2018. Research project application. SANParks, Pretoria, South Africa. Available from https:// www.sanparks.org/conservation/scientific_new/research_needs/ research_project_application.php (accessed October 2018).

Steffen W, Crutzen PJ, McNeill JR. 2007. The Anthropocene: Are humans now overwhelming the great forces of nature? Ambio 36:614621

Stewart GB, Pullin AS, Coles CF. 2007. Poor evidence-base for assessment of windfarm impacts on birds. Environmental Conservation 34:1-11

Sutherland WJ, Pullin AS, Dolman PM, Knight TM. 2004. The need for evidence-based conservation. Trends in Ecology \& Evolution 19:305-308.

Thieme ML, Rudulph J, Higgins J, Takats JA. 2012. Protected areas and freshwater conservation: a survey of protected area managers in the Tennessee and Cumberland River Basins, USA. Journal of Environmental Management 109:189-199.

Tyler C, Pullin AS, Stewart GB. 2006. Effectiveness of management interventions to control invasion by Rhododendron ponticum. Environmental Management 37:513-522.

Uhl-Bien M, Marion R, McKelvey B. 2007. Complexity leadership theory: shifting leadership from the industrial age to the knowledge era. The Leadership Quarterly 18:298-318.

UNEP (United Nations Environment Programme), WCMC (World Commission on Protected Areas) and IUCN (International Union for Conservation of Nature). 2016. Protected planet report 2016. UNEPWCMC, Cambridge, United Kingdom, and IUCN, Gland, Switzerland.

Van Kerkhoff L. 2014. Developing integrative research for sustainability science through a complexity principles-based approach. Sustainability Science 9:143-155.

Van Kerkhoff LE, Lebel L. 2015. Coproductive capacities: rethinking science-governance relations in a diverse world. Ecology and Society 20:14.

Van Wilgen BW, Boshoff N, Smit IPJ, Solano-Fernandez S, Van der Walt L. 2016. A bibliometric analysis to illustrate the role of an embedded research capability in South African National Parks. Scientometrics 107:185-212.

Van Wilgen BW, Govender N, Biggs HC. 2007. The contribution of fire research to fire management: a critical review of a long-term experiment in the Kruger National Park, South Africa. International Journal of Wildland Fire 16:519-530.

Velasco D, et al. 2015. Biodiversity conservation research challenges in the 21st century: a review of publishing trends in 2000 and 2011. Environmental Science \& Policy 54:90-96.

Watson JE, Dudley N, Segan DB, Hockings M. 2014. The performance and potential of protected areas. Nature 515:67-73.

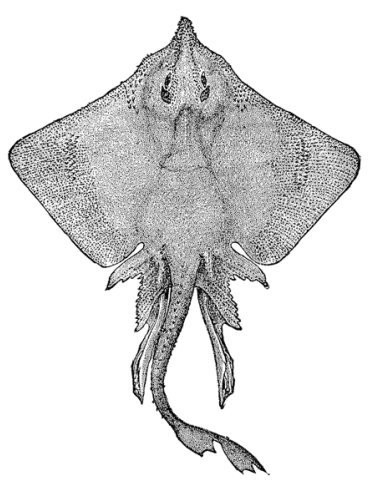

